\title{
Keefektifan Model Pembelajaran Numbered Heads Together Berbantu Media Panelpa (Papan Flanel IPA) Terhadap Hasil Belajar
}

\author{
Hikmah Wiji Hastuti ${ }^{1 *}$, Sunan Baedowi ${ }^{2}$, Qoriati Mushafanah ${ }^{3}$
}

123Jurusan Pendidikan Guru Sekolah Dasar, Fakultas Ilmu Pendidikan, Universitas PGRI Semarang

\author{
A R TI CLEINFO \\ Article history: \\ Received 18 February \\ 2019 \\ Received in revised form \\ 20 March 2019 \\ Accepted 20 April 2019 \\ Available online 20 May \\ 2019 \\ Kata Kunci: \\ model numbered heads \\ together, media panelpa \\ Keywords: \\ model numbered heads \\ together, panelpa media.
}

\begin{abstract}
A B S T R A K
Tujuan dari penelitian ini adalah untuk mengetahui keefektifan model Numbered Heads Together berbantu media Panelpa (papan flanel IPA) terhadap hasil belajar siswa kelas V SDN 03 Sungapan Pemalang. Jenis desain yang digunakan dari pre-experimental design ini adalah one-group pretest-posttest design (satu kelompok pretes postes). Populasi dalam penelitian ini adalah seluruh siswa kelas $\mathrm{V}$ di SD Negeri 03 Sungapan Pemalang. Adapun pengambilan sampel dalam penelitian ini yaitu dengan menggunakan sampling jenuh. Data dalam penelitian ini diperoleh melalui tes tertulis, wawancara, dan dokumentasi. Hasil penelitian menunjukan adanya peningkatan hasil belajar siswa yang dapat dilihat berdasarkan hasil pretest dan posttest yang sudah dilakukan. Rata-rata pretest yang diperoleh siswa sebesar 60,4 dengan nilai tertinggi 88 dan nilai terendah 32 . Sedangkan nilai rata-rata posttest yang diperoleh sebesar 83,2 dengan nilai tertinggi 100 dan nilai terendah 56. Hal tersebut telah dibuktikan dalam pengujian hipotesis, yang menyatakan bahwa nilai thitung lebih besar dari pada nilai $t_{\text {tabel }}(5,433>1,729)$ yang artinya HO ditolak dan Ha diterima. Hal ini berarti bahwa pembelajaran dengan menggunakan model Numbered Heads Together berbantu media Panelpa efektif terhadap hasil belajar siswa.
\end{abstract}

\section{A B S T R A C T}

The purpose of this study was to determine the effectiveness of the Numbered Heads Together model assisted by Panelpa media (IPA flannel board) on the learning outcomes of fifth-grade students of SDN 03 Sungapan Pemalang. This type of research is quantitative research with a preexperimental design method. The type of design used in this pre-experimental design is the one-group pretest-posttest design (one group pretest-posttest). The population in this study were all fifth-grade students at Sungapan Pemalang Elementary School 03. The sampling in this study is by using saturated sampling. The data in this study were obtained through written tests, interviews, and documentation. The results showed an increase in student learning outcomes which can be seen based on the results of the pretest and posttest that have been done. The average pretest obtained by students is 60.4 with the highest value 88 and the lowest value 32 . While the average value of the posttest obtained is 83.2 with the highest value of 100 and the lowest value is 56 . This has been proven in testing the hypothesis, which states that the value of t_count is greater than the value of t_table (5.433> 1.729) which means that $\mathrm{HO}$ is rejected and $\mathrm{Ha}$ is accepted. This means that learning using the Numbered Heads Together model assisted by Panelpa media is effective in student learning outcomes. Keywords: model numbered heads together, panelpa media.

\footnotetext{
${ }^{1}$ Corresponding author.

E-mail addresses: hikmahwiji@gmail.com (Hikmah Wiji Hastuti)
} 


\section{Pendahuluan}

Pendidikan merupakan suatu proses yang diperlukan untuk mendapatkan keseimbangan dan kesempurnaan dalam perkembangan individu maupun masyarakat. Penekanan pendidikan dibanding dengan pengajaran terletak pada pembentukan kesadaran dan kepribadian individu atau masyarakat di samping transfer ilmu dan keahlian. Dengan proses semacam ini suatu bangsa atau negara dapat mewariskan nilai-nilai keagamaan, kebudayaan, pemikiran dan keahlian kepada generasi berikutnya, sehingga mereka betul-betul siap menyongsong masa depan kehidupan bangsa dan negara yang lebih cerah. Pendidikan juga merupakan sebuah aktifitas yang memiliki maksud atau tujuan tertentu yang diarahkan untuk mengembangkan potensi yang dimiliki manusia baik sebagai manusia ataupun sebagai masyarakat dengan sepenuhnya. (Nurkholis ,2013).

Pendidikan merupakan suatu kebutuhan manusia yang sangat penting bagi kelangsungan hidupnya dimasa depan. Dengan adanya pendidikan maka manusia dapat mengetahui tentang apa yang belum diketahui. Pendidikan juga dapat membantu manusia untuk mewujudkan keinginannya. Pendidikan yang semakin maju dari suatu bangsa maka semakin maju dan terarah juga kesejahteraan masyarakatnya. Sebagaimana tercantum dalam dalam Undang-Undang Nomor 20 tahun 2003 tentang sistem pendidikan nasional pasal 1 ayat 1 menyebutkan bahwa :

"Pendidikan adalah usaha sadar dan terencana untuk mewujudkan suasana belajar dan proses pembelajaran agar peserta didik secara aktif mengembangkan potensi dirinya untuk memiliki kekuatan spiritual, keagamaan, pengendalian diri, kepribadian, kecerdasan, akhlak mulia, serta keterampilan yang diperlukan dirinya, masyarakat, bangsa dan Negara".

Oleh karena itu peran pendidikan amatlah penting dan sangat dibutuhkan dalam kehidupan bermasyarakat pada umumnya. Berdasarkan pengertian diatas dapat disimpulkan bahwa Pendidikan merupakan suatu proses pembelajaran yang dilakukan dengan sadar dan sistematis untuk mengembangkan potensi yang dimiliki siswa sehingga mengalami perubahan dalam dirinya sebagai penunjang keberhasilan dikehidupan mendatang.

Siswa menjadi sasaran utama dalam pelaksanaan sistem pendidikan. Sistem pendidikan yang dilaksanakan diharapkan mampu menghasilkan insan yang berkualitas dari siswa yang melaksanakan pembelajaran dalam sistem pendidikan yang diterapkan. Jika pendidikan yang dilaksanakan belum mampu memberikan perubahan yang baik bagi siswanya maka dapat dikatakan bahwa pendidikan yang diterapkan belum mampu mencapai tujuan pendidikan yang dimaksud.

Dalam mewujudkan proses pembelajaran yang membuat siswa secara aktif mengembangkan potensi dirinya, seorang guru harus menguasai strategi belajar mengajar. Strategi pembelajaran dalam hal ini adalah penguasaan guru mengenai model, metode, serta media pembelajaran.Agar proses pembelajaran berhasil, guru sebagai pendidik harus dapat menciptakan suasana belajar yang menyenangkan dan menarik, tidak monoton, tidak membosankan, serta membuat siswa menjadi lebih aktif, kritis dan kreatif.

Berdasarkan hasil pengamatan dan wawancara dengan guru kelas V SDN 03 Sungapan bahwa pertama, siswa masih kesulitan dalam mata pelajaran IPA. Kedua, dalam proses pembelajaran guru belum menerapkan model pembelajaran. Ketiga, guru masih menggunakan metode ceramah dalam proses belajar mengajar. Pada saat menjelaskan guru cenderung menyampaikan materi terlalu banyak dengan menggunakan sistem pembelajaran satu arah. Dimana disini siswa hanya sebagai pendengar saja dan guru masih monoton. Hal ini menyebabkan siswa kurang bisa memahami pengetahuan karena kurangnya keaktifan siswa dalam proses pembelajaran. Dengan adanya kegiatan pembelajaran yang seperti itu maka dapat dikatakan bahwa belum adanya keberhasilan dalam pembelajaran. Terakhir, media yang digunakan guru dalam menyampaikan pembelajaran belum maksimal hanya memanfaatkan papan tulis dan buku paket. Akibat yang ditimbulkan dari masalah-masalah tersebut antara lain belum adanya penggunaan model pembelajaran, kurang aktifnya siswa dalam proses pembelajaran dan media pembelajaran yang digunakan hanya papan tulis dan buku paket, sehingga masih rendahnya hasil belajar siswa.

Keseluruhan siswa kelas V adalah 20 yang terdiri dari 10 siswa laki-laki dan 10 siswa perempuan. KKM IPA yang ditentukan SD N 03 Sungapan adalah 69. Dengan catatan 15 tidak tuntas dan 5 tuntas.

Hasil belajar siswa yang baik adalah tujuan utama dalam pembelajaran. Tetapi pembelajaran yang biasa dilakukan tidak menuntut keaktifan siswa untuk berfikir secara aktif dan kreatif dalam pembelajaran, sehingga mengakibatkan siswa menjadi kurang berminat dalam pembelajaran. Jika kemampuan berfikir siswa rendah dalam mengikuti pembelajaran, maka yang mungkin terjadi adalah siswa tidak dapat menyerap materi yang disampaikan guru.

Guru dalam proses pembelajaran harus dapat menciptakan suasana yang kreatif dan menyenangkan agar siswa dapat mengikuti pelajaran secara aktif dengan menggunakan metode, model, ataupun media pembelajaran yang sesuai dengan materi apa yang akan disampaikan. Karena 
pembelajaran yang menyenangkan dapat tercapai apabila guru mampu mewujudkan suatu proses belajar mengajar yang baik dan menarik minat siswa, maka perlu adanya variasi dalam suatu strategi pembelajaran baik metode, model maupun media pembelajaran. Model Numbered Heads Together merupakan salah satu model pembelajaran yang dapat digunakan untuk membantu mengatasi permasalahan yang ada.

Model pembelajaran yang digunakan dalam penelitian ini yaitu model pembelajaran kooperatif tipe Numbered Heads Together (NHT) dalam tipe ini siswa dapat belajar secara berkelompok, bekerjasama untuk menyatukan ide-ide yang dimiliki siswa dan berani mengemukakan pendapatnya di depan kelas yang akan meningkatkan motivasi siswa untuk belajar dan aktif dalam proses pembelajaran sebagaimana (Agisni, 2016).

Pada pembelajaran dengan menggunakan model NHT, saat guru menjelaskan kemungkinan siswa masih banyak yang berbicara sendiri dengan teman sebangku dan mengerjakan tugas mata pelajaran lain. Pada kegiatan diskusi, biasanya siswa akan mengabaikan hasil diskusi ketika pelajaran kimia selesai, sehingga mereka tidak mempunyai catatan hasil diskusi. Oleh karena itu, perlu kiranya pembelajaran model NHT dilengkapi dengan media yang bisa mengatasi hambatan yang telah disebutkan sebelumnya (Andriyani ,2015).

Model pembelajaran NHT di atas didasarkan pada keunggulannya. Kaagan (2009:116-117) menyampaikan bahwamodel pembelajaran NHT memiliki keuntungan yaitu siswa akan diajarkan mengenai Social skill, knowledge building, procedure learning, processing info, thinkhing skill, team building, communication skill, decision making dan presenting info, sehingga siswa akan lebih aktif dan mandiri dalam kegiatan pembelajaran sehingga hasil belajarnya juga akan meningkat (Harmini ,2107).

Model pembelajaran Numbered Heads Together merupakan salah satu model dalam pembelajaran kooperatif. Pembelajaran kooperatif adalah pembelajaran yang mengutamakan kerjasama untuk mencapai tujuan pembelajaran (Majid, 2014: 174). Cara ini bertujuan untuk melibatkan semua siswa aktif dalam kegiatan belajar mengajar. Selain model untuk menunjang pembelajaran juga perlu adanya perantara dalam menyampaikan materi pelajaran yaitu dengan menggunakan media pembelajaran. Menurut Arsyad (2016: 10) media pembelajaran adalah segala sesuatu yang dapat digunakan untuk menyampaikan pesan atau informasi dalam proses belajar mengajar sehingga dapat merangsang perhatian dan minat siswa dalam belajar. Media papan flanel merupakan media grafis yang efektif untuk menyajikan pesan-pesan tertentu kepada sasaran tertentu pula. Bentuk papan flanel adalah papan yang berlapis kain flanel, sehingga gambar yang akan disajikan dapat dipasang dan dicopot atau dilepas dengan mudah dapat dapat dipakai berkali-kali. Dalam suatu proses pembelajaran apabila menggunakan media pembelajaran maka akan lebih mempermudah siswa dalam memahami suatu materi pelajaran.

Shoimin (2017: 107) mengemukakan model pembelajaran Numbered Head Together yaitu mengacu pada belajar kelompok siswa, masing-masing anggota memiliki bagian tugas (pertanyaan) dengan nomor yang berbeda-beda.

Adapun langkah-langkah model pembelajaran Numbered Head Together Shoimin (2017: 107) mengemukakan model pembelajaran Numbered Head Together yaitu mengacu pada belajar kelompok siswa, masing-masing anggota memiliki bagian tugas (pertanyaan) dengan nomor yang berbeda-beda.

Adapun langkah-langkah model pembelajaran Numbered Head Together adalah sebagai berikut: a) Siswa dibagi dalam kelompok. Setiap siswa dalam setiap kelompok mendapat nomor, b) Guru memberikan tugas dan masing-masing kelompok mengerjakannya, c) Kelompok mendiskusikan jawaban yang benar dan memastikan tiap anggota kelompok dapat mengerjakannya/mengetahui jawabannya dengan baik, d) Guru memanggil salah satu nomor siswa dan nomor yang dipanggil keluar dari kelompoknya melaporkan atau menjelaskan hasil kerja sama mereka, e) Tanggapan dengan teman yang lain, kemudian guru menunjuk nomor yang lain, dan f) Kesimpulan.

Kelebihan model pembelajaran Numbered Head Together yaitu: a) Setiap murid menjadi siap, b) Dapat melakukan diskusi dengan sungguh-sungguh, c) Murid yang pandai dapat mengajari murid yang kurang pandai, d) Terjadi interaksi secara intens antarsiswa dalam menjawab soal, dan e) Tidak ada murid yang mendominasi dalam kelompok karena ada nomor yang membatasi. Sedangkan kekurangan model pembelajaran Numbered Head Together yaitu: a) Tidak terlalu cocok diterapkan dalam jumlah siswa banyak karena membutuhkan waktu yang lama, dan b) Tidak semua anggota kelompok dipanggil oleh guru karena kemungkinan waktu yang terbatas.

Arsyad (2016: 10) media pembelajaran adalah segala sesuatu yang dapat digunakan untuk menyampaikan pesan atau informasi dalam proses belajar mengajar sehingga dapat merangsang perhatian dan minat siswa dalam belajar. Sanaky (2013: 3) Media pembelajaran adalah sebuah alat yang berfungsi dan dapat digunakan untuk menyampaikan pesan pembelajaran.

Dari beberapa pendapat diatas dapat disimpulkan bahwa media pembelajaran merupakan suatu alat yang dapat digunakan untuk menyampaikan dan menyalurkan pesan guna mencapai tujuan 
pembelajaran sehingga dapat menarik perhatian dan minat belajar siswa. Media pembelajaran digunakan sebagai alat bantu yang dapat menciptakan kondisi belajar yang kondusif agar dapat membantu pembelajar untuk menerima pesan berupa pengetahuan, sikap dan ketrampilan secara efisien dan efektif. Tujuan media pembelajaran sebagai alat bantu pembelajaran untuk : a) Mempermudah proses pembelajaran dikelas, b) Meningkatkan efisiensi proses pembelajaran, c) Menjaga relevansi antara materi pelajaran dengan tujuan belajar, dan d) Membantu konsentrasi pembelajar dalam proses pembelajaran.

Gagne (1970) menyatakan bahwa media adalah berbagai jenis komponen dalam lingkungan siswa yang dapat merangsangnya untuk belajar. 9 Heinich, dan kawan-kawan (1982) mengemukakan istilah medium sebagai perantara yang mengantarkan informasi antara sumber dan penerima. Jadi televisi, film, foto, radio, rekaman audio, gambar yang diproyeksikan, bahan-bahan cetakan, dan sejenisnya adalah media komunikasi. Apabila media tersebut membawa informasi yang bertujuan instruksional atau mengandung maksud pengajaran maka media tersebut disebut media pengajaran.10 Pendapat lainnya, yaitu Yusuf Hadi Miarso membatasi pengertian media dengan segala sesuatu yang dapat digunakan untuk menyalurkan pesan yang dapat merangsang pikiran, perasaan, perhatian, dan kemauan siswa untuk belajar. Selain pengertian yang telah disebutkan di atas, terdapat pengertian media yang lebih luas. Sebagaimana dikemukakan oleh Gerlach dan Ely media adalah " A medium, conceived is any person, material or event that establishs condition which enable the lerner to acquire knowledge, skill, and attitude." Menurut Gerlach secara umum media itu meliputi orang, bahan, peralatan, atau kegiatan yang menciptakan kondisi yang memungkinkan siswa memperoleh pengetahuan, keterampilan, dan sikap. Jadi dalam pengertian ini media bukan hanya perantara seperti TV, radio, slide, bahan cetakan, tetapi meliputi orang atau manusia sebagai sumber belajar atau kegiatan semacam diskusi, seminar, karyawisata, simulasi, dan lain sebagainya yang dikondisikan untuk menambah pengetahuan dan wawasan, mengubah sikap siswa, atau untuk menambah keterampilan (Mahnun ,2012).

"Media" berasal dari bahasa latin yang merupakan bentuk jamak dari "medium", secara harfiah berarti perantara atau pengantar. Association for Education and Communication Technology (AECT), mengartikan kata media sebagai segala bentuk dan saluran yang dipergunakan untuk proses informasi. National Education Association (NEA) mendefinisikan media sebagai segala benda yang dapat dimanipulasikan, dilihat, didengar, dibaca atau dibicarakan beserta instrumen yang dipergunakan untuk kegiatan tersebut. Sedangkan Heinich, dkk (1982) mengartikan istilah media sebagai "the term refer to anything that carries information between a source and a receiver"(Nurseto ,2011).

Media papan flanel merupakan media grafis yang efektif untuk menyajikan pesan-pesan tertentu kepada sasaran tertentu pula. Bentuk papan flanel adalah papan yang berlapis kain flanel, sehingga gambar yang akan disajikan dapat dipasang dan dicopot atau dilepas dengan mudah dapat dapat dipakai berkali-kali.

Tujuan dari media papan flanel adalah: (1) membantu pengajar untuk menerangkan bahan pelajaran,(2) mempermudah pemahaman pembelajar tentang bahan pelajaran, (3) agar bahan pelajaran lebih menarik. Keuntungan menggunakan papan flanel sebagai media pembelajaran adalah: (1) gambargambar dengan mudah ditempelkan (2) efisiensi waktu dan tenaga (3) menarik perhatian pembelajar (4) memudahkan pengajar menjelaskan materi pelajaran. (Sanaky, 2013: 71)

Dari uraian diatas maka dapat disimpulkan bahwa media papan flanel merupakan media yang efektif dan dapat menarik perhatian siswa dalam proses pembelajaran, disini peneliti akan menggunakan media papan flanel yang akan digunakan untuk membantu pembelajaran pada materi IPA.

Menurut Nash dalam Samatowa (2010: 3) mengemukakan bahwa IPA adalah suatu cara atau metode untuk mengamati alam. Nash juga menjelaskan bahwa cara IPA mengamati dunia ini bersifat analisis, lengkap, cermat, serta menghubungkannya antara suatu fenomena dengan fenomena lain, sehingga keseluruhannya membentuk suatu prespektif yang baru tentang objek yang diamatinya.

Dalam pembelajaran IPA yang sudah di kemukakan di atas, maka pembelajaran IPA itu ilmu yang mempelajari suatu alam yang bersifat analisis, lengkap dengan menghubungkan kumpulan-kumpulan pengetahuan alam yang berupa fakta dan sudah mempunyai konsep yang benar, sehingga mengajarkan kepada manusia untuk menjaga keindahan alam agar tidak untuk dirusak dan tidak dimanfaatkan secara terus-menerus.

Sains merupakan cara mencari tahu tentang alam secara sistematis untuk menguasai pengetahuan, fakta-fakta, konsep-konsep, prinsip-prinsip, proses penemuan, dan memiliki sikap ilmiah. Pendidikan sains di sekolah dasar bermanfaat bagi siswa untuk mempelajari diri sendiri dan alam sekitar.

Dalam pernyataan tersebut maka sains merupakan suatu proses kegiatan untuk mempelajari alam melalui kerja ilmiah untuk menghasilkan pemahaman konsep-konsep, prinsip-prinsip, hukum-hukum serta sikap ilmiah sehingga bermanfaat bagi kehidupan sehari-hari.

Berdasarkan penjelasan di atas dapat disimpulkan bahwa pembelajaran IPA merupakan suatu ilmu pengetahuan yang mempelajari suatu fenomena atau gejala yang ada pada alam semesta. Dengan 
mempelajari IPA maka siswa akan mendapatkan banyak pengetahuan tentang alam yang merupakan tempat mereka hidup, sehingga mereka mampu berfikir bagaimana cara menjaga alam tempat tinggal mereka serta akibat yang timbul apabila alam tersebut menjadi rusak.

Berbagai alasan yang menyebabkan mata pelajaran IPA di masukkan di dalam suatu kurikulum sekolah yaitu :(1) Bahwa IPA berfaedah bagi suatu bangsa, kiranya tidak perlu dipersoalkan panjang lebar. Kesejahteraan meteril suatu bangsa banyak sekali tergantung pada kemampuan bangsa itu dalam bidang IPA, sebab IPA merupakan dasar tekhnologi, sering disebut-sebut sebagai tulang punggung pembangunan, (2) Bila diajarkan IPA menurut cara yang tepat, maka IPA merupakan suatu mata pelajaran yang memberikan kesempatan berfikir kritis, misalnya IPA diajarkan dengan mengikuti metode "menemukan sendiri", (3) Bila IPA diajarkan melalui percobaan-percobaan yang dilakukan sendiri oleh anak, maka IPA tidaklah merupakan mata pelajaran yang bersifat hafalan belaka, (4) Mata pelajaran in i mempunyai nilai-nilai pendidikan yaitu mempunyai potensi yang dapat membantuk kepribadian anak secara keseluruhan. (Samatowa, 2010:6)

Berdasarkan eksplorasi peneliti, ditemukan beberapa tulisan yang berkaitan dengan penelitian ini pertama adalah penelitian yang dilakukan oleh Ismi Saumi pada tahun 2017 mahasiswa Pendidikan Guru Sekolah Dasar Fakultas Ilmu pendidikan Universitas PGRI Semarang yang berjudul "Keefektifan Model Numbered Head Together (NHT) Berbantu Media Audiovisual Terhadap Hasil Belajar Tema 8 Lingkungan Sahabat Kita untuk Siswa Kelas V SDN 1 Mojoagung" Dilaksanaknnya penelitian ini bertujuan untuk meningkatkan hasil belajar dengan menggunkan model NHT pada siswa kelas V SDN 1 Mojoagung.

Kedua yaitu penelitian yang dilakukan oleh Novi Astiani pada tahun 2018 mahasiswa Pendidikan Guru Sekolah Dasar Universtas Pendidikan Indonesia Kampus Tasikmalaya yang berjudul "Pengaruh Media Papan Flanel terhadap Hasil Belajar Siswa pada Pembelajaran IPS di Sekolah Dasar" Dilaksanakannya penelitian ini bertujuan untuk meningkatkan hasil belajar dengan menggunakan media papan flanel.

Tujuan penelitian ini adalah untuk mengetahui keefektifan model Numbered Heads Together berbantu media Panelpa (Papan flanel IPA) terhadap hasil belajar siswa kelas V SD Negeri 03 Sungapan Pemalang .

\section{Metode}

Metode penelitian yang digunakan dalam penelitian ini yaitu metode penelitian kuantitatif. Sugiyono (2015: 7) mengatakan metode penelitian kuantitatif dapat diartikan sebagai metode penelitian yang berlandaskan pada filsafat positivisme, digunakan untuk meneliti pada populasi atau sampel tertentu, pengumpulan data menggunakan instrumen penelitian, analisis data bersifat kuantitatif/statistik dengan tujuan untuk menguji hipotesis yang telah ditetapkan. Desain penelitian yang digunakan yaitu preexperimental design dengan bentuk one-group pretest-posttest design. Menurut Sugiyono (2015:74) dalam desain ini menggunakan pretest sebelum diberi perlakuan dengan demikian hasil perlakuan dapat diketahui lebih akurat, karena dapat membandingkan dengan keadaan sebelum diberi perlakuan.

Adapun populasi dari penelitian ini adalah semua siswa kelas V di SD Negeri 03 Sungapan Pemalang. Sampel yang akan digunakan dalam penelitian ini sebanyak 1 kelas yang berjumlah 20 siswa, terdiri dari 10 siswa laki - laki dan 10 siswa perempuan. Dimana pada pembelajaran hari pertama siswa belum diberi perlakuan yaitu masih menggunakan pembelajaran seperti biasa dengan metode ceramah sedangkan pembelajaran hari kedua siswa diberi perlakuan dengan menggunakan model Numbered Heads Together dan media Panelpa (papan flanel IPA).

Pada penelitian ini peneliti menggunakan teknik sampling Nonprobability Sampling dengan jenis Sampling Jenuh, karena semua anggota populasi dijadikan sampel .Sugiyono (2015: 81) mengemukakan teknik sampling adalah merupakan teknik pengambilan sampel. Pada penelitian ini peneliti menggunakan Sampling Jenuh. Sugiyono (2015: 85) mengatakan Sampling Jenuh adalah teknik penentuan sampel bila semua anggota populasi digunakan sebagai sampel.

Teknik pengumpulan data yang digunakan dalam penelitian ini yaitu menggunakan wawancara, tes, dan dokumentasi. Wawancara digunakan sebagai teknik pengumpulan data apabila peneliti ingin melakukan studi pendahuluan untuk menemukan permasalahan yang harus diteliti dan juga apabila peneliti ingin mengetahui hal-hal dari responden yang lebih mendalam Sugiyono (2015: 137). Metode ini digunakan untuk menemukan permasalahan yang akan diteliti dengan cara bertanya kepada pihak yang terkait.

Tes digunakan untuk mengetahui hasil belajar siswa dengan membagikan soal kepada siswa. Arikunto (2013: 46) mengemukakan tes adalah serentetan pertanyaan atau latihan serta alat lain yang digunakan untuk mengukur ketrampilan, pengetahuan, kemampuan atau bakat yang dimiliki oleh individu atau kelompok. 
Penelitian ini menggunakan tes prestasi, yaitu tes yang digunakan untuk mengukur hasil belajar atau pencapaian seseorang setelah mempelajari sesuatu. Tes yang dilakukan dalam penelitian ini dibagi menjadi dua yaitu pretest dan posttest. Pretest adalah tes yang dilakukan sebelum dilaksanakan proses pembelajaran, sedangkan posttest adalah tes yang dilakukan setelah proses pembelajaran. Menggunakan metode tes ini dapat diperoleh data hasil belajar siswa yang diambil dari hasil evaluasi siswa.

Dokumentasi digunakan untuk mendapatkan data-data yang diperlukan. Dalam penelitian ini dokumentasi dilakukan untuk memperoleh data nama peserta didik, nilai siswa, jumlah siswa dan kegiatan siswa dalam pembelajaran.

\section{Hasil dan Pembahasan}

Analisis data awal dapat dilihat dari hasil nilai pretest sebelum diberi perlakuan dan analisis data akhir dapat dilihat dari hasil nilai posttest sesudah diberi perlakuan dengan menggunakan model pembelajaran Numbered Heads Together berbantu media PANELPA. Hasil nilai posttest lebih baik dari nilai pretest, setelah diberi perlakuan didapat hasil belajar yang berbeda. Pada nilai pretest yang telah dilaksanakan diperoleh nilai rata-rata sebesar 60,4 dan tes akhir yaitu posttest dengan nilai rata-rata hasil belajar diperoleh sebesar 83,2. Perbedaan nilai rata-rata pretest dan posttest dapat dikatakan bahwa model pembelajaran Numbered Heads Together berbantu media Panelpa dapat meningkatkan hasil belajar siswa, yang dibuktikan dengan nilai rata-rata posttest lebih baik dari nilai rata-rata pretest.

Dari data awal yang diperoleh dari nilai pretest yang dianalis dengan uji liliefors untuk mengetahui kenormalan data dari kelas yang akan digunakan untuk penelitian yaitu dengan tingkatan signifikan $5 \%$ dan $\mathrm{n}$ sebesar 20 sehingga diperoleh $\mathrm{L}_{\text {tabel }} 0,190$ dan didapatkan $\mathrm{L}_{0}$ sebesar 0,1643 maka 0,1643<0,190 maka $\mathrm{H}_{0}$ diterima. Berdasarkan hasil uji normalitas data awal tersebut dapat disimpulkan bahwa populasi berdistribusi normal.

Pada analisis data akhir menggunakan uji liliefors dengan tingkatan signifikan 5\% perhitungan uji normalitas diperoleh $L_{\text {hitung }}=0,1628$ dan $L_{\text {tabel }}=0,190$ dengan $n=20$ sehingga dapat disimpulkan bahwa $\mathrm{L}_{\text {hitung }}<\mathrm{L}_{\text {tabel }}$ yaitu maka $\mathrm{H}_{0}$ dierima. Berdasarkan hasil tersebut dapat dikatakan bahwa data berdistribusi normal. Pada hasil perhitungan nilai awal dan nilai akhir menunjukkan bahwa kelas berdistribusi normal.

Kemudian berdasarkan data analisis awal dan akhir untuk mengetahui tingkat ketuntasan hasil belajar siswa tersebut data diuji menggunakan uji $t$ untuk mengetahui adanya perbedaan pada kemampuan akhir setelah siswa diberi perlakuan, dimana diharapkan bila terjadi perbedaan pada kemampuan akhir adalah karena adanya pengaruh perlakuan. Berdasarkan perhitungan uji t dari data awal dan data akhir diperoleh $t_{\text {hitung }} 5,433 \mathrm{t}_{\text {tabel }}$ 1,729. Jadi nilai $\mathrm{t}_{\text {hitung }}>\mathrm{t}_{\text {tabel, sehingga }} \mathrm{H}_{\mathrm{o}}$ ditolak dan $\mathrm{H}_{\mathrm{a}}$ diterima maka dapat disimpulkan bahwa model pembelajaran Numbered Heads Together berbantu media Panelpa efektif terhadap hasil belajar siswa dan terdapat perbedaan daripada menggunakan metode ceramah.

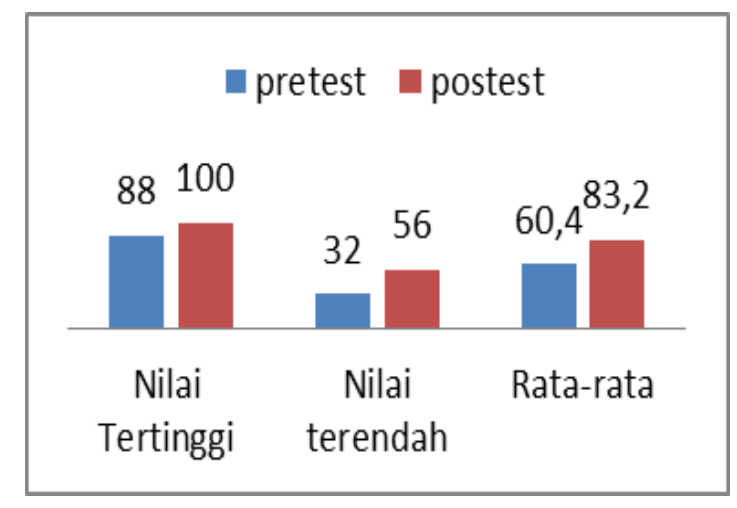

Gambar 1. Nilai Terendah, Tertinggi dan Rata-rata Pretest-Posttest

Dari hasil perhitungan tersebut model pembelajaran Numbered Heads Together berbantu media Panelpa dapat meningkatkan hasil belajar siswa kelas V.

Pada proses pembelajaran di kelas setelah diberi perlakuan siswa lebih mudah berinteraksi sehingga membuat siswa lebih semangat, aktif dan kerjasama antar siswa juga semakin meningkat, hal ini tampak saat siswa aktif berdiskusi dengan kelompok. Berbeda dengan siswa sebelum diberi perlakuan yaitu siswa masih cenderung individual dan kurang aktif dalam proses pembelajaran. Model pembelajaran 
Numbered Heads Together menarik dan mudah untuk diaplikasikan dalam proses pembelajaran. Selama proses pembelajaran berlangsung siswa sangat senang ,aktif dan siswa yang sudah maju ke depan untuk menjawab pertanyaan yang diberikan guru, siswa akan mendapatkan hadiah dari guru untuk itu model Numbered Heads Together efektif digunakan. Penelitian ini relevan dengan hasil penelitian Ismi Saumi yang mengatakan bahwa model Numbered Heads Together merupakan model yang efektif digunakan dan mempunyai pengaruh dalam aktivitas dan peningkatan hasil belajar siswa. Mutia Agisni Mulyana (2016) Menyatakan bahwa Model kooperatif tipe Numbered Heads Together (NHT) dapat meningkatkan hasil belajar siswa pada materi kenampakan alam dan sosial budaya. Siti Nuryanti (2014) juga menyatakan penerapan model pembelajaran kooperatif tipe Numbered Head Together dapat meningkatkan hasil belajar IPA siswa Kelas IV SD Negeri 3 Tondo Palu. Sejalan dengan itu penelitian Witari (2017) menyatakan bahwa model pembelajaran NHT berpengaruh terhadap hasil Belajar IPA.

\section{Simpulan dan Saran}

Berdasarkan rumusan masalah, analisis data penelitian dan pembahasan, maka peneliti membuat kesimpulan bahwa Model pembelajaran Numbered Heads Together berbantu media Panelpa efektif terhadap hasil belajar siswa kelas V SD Negeri 03 Sungapan Pemalang. Hal ini dibuktikan bahwa rata-rata hasil belajar siswa berdasarkan pada hasil pretest yang telah dilakukan diperoleh sebesar 60,4 dan ratarata nilai posttest yang diperoleh sebesar 83,2 dan dibuktikan pula dari hasil uji t yang diperoleh $t_{\text {hitung }}$ $5,433 t_{\text {tabel }} 1,729$ dengan taraf signifikan $5 \%$ karena $t_{\text {hitung }}>t_{\text {tabel }}$ yaitu 5,433 $>1,729$ artinya $\mathrm{H}_{0}$ ditolak dan $\mathrm{H}_{\mathrm{a}}$ diterima. Maka dapat dikatakan efektif hal ini dapat dilihat adanya peningkatan hasil belajar siswa banyak yang mendapatkan nilai diatas KKM $>75$.

Dari hasil paparan diatas maka perlu adanya beberapa saran yang harus disampaikan, yakni bahwa uru dapat menggunakan model pembelajaran Numbered Heads Together dalam pembelajaran di sekolah sebagai model pembelajaran yang menarik dan mampu meningkatkan hasil belajar siswa. Kemudian siswa diharapkan untuk bisa berpartisipasi secara aktif agar tujuan pembelajaran tercapai secara optimal. Dan peneliti lain dapat melanjutkan penelitian dengan cakupan hasil belajar yang lebih luas, tidak terbatas pada aspek kognitif saja.

\section{Daftar Rujukan}

Arikunto, Suharsimi.2013.Prosedur Penelitian: Suatu Pendekatan Praktik. Jakarta: Rineka Cipta.

Agisni ,Mutia (2016) Penerapan Model Kooperatif Tipe Numbered Heads Together (NHT) Untuk Meningkatkan Hasil Belajar Siswa Pada Materi Kenampakan Alam Dan Sosial Budaya . Jurnal Pena Ilmiah: Vol. 1, No. 1 (2016)

Andriyani ,Dhini (2015). Penerapan Model Pembelajaran Numbered Heads Together (Nht) Dilengkapi Catatan Terbimbing Untuk Meningkatkan Kemampuan Berpikir Kritis Dan Prestasi Belajar Pada Materi Hasil Kali Kelarutan Kelas Xi Sma Negeri 2 Sukoharjo Tahun Pelajaran 2013/2014 . Jurnal Pendidikan Kimia (JPK), Vol. 4 No. 2 Tahun 2015.

Arsyad, Azhar. 2014. Media Pembelajaran. Jakarta: PT RajaGrafindo Persada.

Astianti, Novi (2018). Pengaruh Media Papan Flanel terhadap Hasil Belajar Siswa pada Pembelajaran IPS di Sekolah Dasar.Volume V, $\quad$ No. 2 (2018)http://ejournal.upi.edu/index.php/pedadidaktika/article/view/7149 Diakses pada tanggal 3 Oktober 2018 jam 08:24

Harmini ,Sri (2017). Penerapan Model Pembelajaran Numbered Heads Together Untuk Meningkatkan Aktivitas Belajar Dan Hasil Belajar Ips Siswa Kelas Viii G Smpn 2 Ponorogo . Jurnal Studi Sosial Volume 2 Nomor 1 Juli 2017 hal 13-21 ISSN : 2528-6293

Majid, Abdul. 2014. Strategi Pembelajaran. Bandung: PT Remaja Rosdakarya Offset. Dasar. Jakarta : PT. Indeks 
Mahnun ,Nunu (2012). MEDIA PEMBELAJARAN (Kajian terhadap Langkah-langkah Pemilihan Media dan Implementasinya dalam Pembelajaran) . Jurnal Pemikiran Islam; Vol. 37, No. 1 Januari-Juni 2012.

Mutia Agisni Mulyana, Nurdinah Hanifah, Asep Kurnia Jayadinata. 2016. Penerapan Model Kooperatif Tipe Numbered Heads Together (NHT) Untuk Meningkatkan Hasil Belajar Siswa Pada Materi Kenampakan Alam Dan Sosial Budaya. Jurnal Pena Ilmiah UPI. Vol 1 No 1

Nurkholis (2013). Pendidikan Dalam Upaya Memajukan Teknologi . Jurnal Kependidikan, Vol. 1 No. 1 Nopember 2013

Nurseto ,Tejo (2011). Membuat Media Pembelajaran Yang Menarik . Jurnal Ekonomi \& Pendidikan, Volume 8 Nomor 1, April 2011

Sanaky, Hujair AH. 2013. Media Pembelajaran Interaktif Inovatif. Yogyakarta:

Saumi, Ismi (2017). Keefektifan Model Numbered Head Together (NHT) Berbantu Media Audiovisual Terhadap Hasil Belajar Tema 8 Lingkungan Sahabat Kita untuk Siswa Kelas V SDN 1 Mojoagung.

Shoimin, Aris. 2017. 68 Model Pembelajaran Inovatif dalam Kurikulum 2013.Yogyakarta: Ar-Ruzz Media

Sisdiknas. 2011. Undang-Undang Sistem Pendidikan Nasional.Yogyakarta: Pustaka Pelajar.

Siti Nuryanti. 2014. Penerapan Model Pembelajaran Kooperatif Tipe Numbered Head Together (Nht) Untuk Meningkatkan Hasil Belajar Siswa Pada Mata Pelajaran Ipa Kelas IV Sd Negeri 3 Tondo. Jurnal Diknas. Volume 2 No 2.

Sugiyono. 2015. Metode Penelitian Kuantitatif Kualitatif dan R\&D. Bandung :Alfabeta.

Witari, I Gusti Ayu. 2017. Pengaruh Model Pembelajaran Kooperatif Tipe Numbered Head Together (NHT) Terhadap hasil Belajar IPA Siswa Kela IV di SDN Gugus I Kecamatan sawan Tahun Pelalajaran 201/2017. Jurnal MImbar PGSD Universitas Pendidikan Ganesha Volume 3 Nmor 4. 